\title{
Approach to the knowledge of preservation of pleistocenic bone: The case of a Gomphothere cranium from the site of Tepeticpac, Tlaxcala, Mexico
}

\section{Luisa Straulino ${ }^{1, *}$, Luisa Mainou ${ }^{1}$, Teresa $\mathrm{Pi}^{2,3}$, Sergey Sedov ${ }^{3}$, Aurelio López-Corral ${ }^{4}$, Ramón Santacruz-Cano ${ }^{4}$, and Alonso Gabriel Vicencio-Castellanos ${ }^{4}$}

${ }^{1}$ Coordinación Nacional de Conservación del Patrimonio cultural, Instituto Nacional de Antropología e Historia, Ex Convento de Churubusco, Xicoténcatl y General Anaya s/n, Col. San Diego Churubusco, Coyoacán, Mexico City, Mexico.

${ }^{2}$ Laboratorio Nacional de Geoquímica y Mineralogía (LANGEM), Universidad Nacional Autónoma de México, 04510, Mexico City, Mexico.

${ }^{3}$ Instituto de Geología, Universidad Nacional Autónoma de México, 04510, Mexico City, Mexico.

${ }^{4}$ Centro INAH Tlaxcala, Instituto Nacional de Antropología e Historia, Avenida Diego Muñoz Camargo No. 26, Colonia Centro, C.P. 90000, Tlaxcala, Tlaxcala, Mexico.

*azucarylimon@gmail.com

\begin{abstract}
An almost complete cranium of a gomphoterium found in Tepeticpac, Tlaxcala, was analyzed with X-ray diffraction (XRD), Petrography and Scanning Electron Microscopy with Energy Dispersive Spectroscopy (SEM-EDS) to stablish the transformations of the bone during its burial. The analyses assessed that the bone mineral (bioapatite) had suffered modifications in mineral composition, "crystallinity index", cell parameters and $\mathrm{CO}_{2}$ content. However, the paleohistological structure of the bone was not significantly affected, although evidence of microbial attack was found in the bone surfaces. The filling minerals of bone macro and micro porosity were also analyzed; its main filling minerals are calcite (micrite and sparite), clays, and minerals of volcanic origin.
\end{abstract}

Key words: ; bone; gomphotere; mineralization; X-ray diffraction; petrography.

\section{RESUMEN}

Un cráneo casi completo de gonfoterio encontrado en Tepeticpac, Tlaxcala, se estudió mediante difracción de rayos $X$, petrografía $y$ microscopía electrónica de barrido con espectroscopía de dispersión de rayos $X$ para establecer las transformaciones que sufrió el hueso durante su enterramiento. Estos análisis permitieron determinar que el mineral del hueso (bioapatita) experimentó modificaciones en cuanto a su composición mineral, índice de cristalinidad, parámetros de celda $y$ contenidos de $\mathrm{CO}_{2}$. No obstante, la estructura paleohistológica del hueso no se transformó de manera significativa, aunque se encontraron evidencias de ataque biológico en las áreas superficiales de las muestras de hueso. Los minerales de relleno de la macro y microporosidad del hueso también se caracterizaron y se comprobó que los minerales más abundantes son calcita (micrita y esparita), arcillas de tipo expansible y minerales de origen volcánico.

Palabras clave: Palehistología; hueso; gonfoterio; mineralización; difracción de rayos $X$; petrografía.

\section{INTRODUCTION}

An almost complete skull of a proboscide was found in Tlaxcala in 2014. The remains were identified by Dra. Maria Teresa Alberdi as a gomphothere (Cuvieronius sp.) based on the morphology of the dentition and the spiral-shaped band of tusks enamel.

The cortical bone, better preserved than the trabecular bone, showed heterogeneity in color, density and porosity. Several analyses have been carried out to understand the bone conservation and the postmortem bone mineral transformations (diagenesis and possible fossilization processes) with the aim to propose better preservation methodologies for the cranium. This remain is now located in the Coordinación Nacional de Conservación del Patrimonio Cultural for its restoration and then it will be at display at the Museo Regional de Tlaxcala.

Pleistocene megafauna remains are quite frequent in Mexico (Ferrusquía-Villafranca et al., 2010). The primary interest in paleontological remains has been taxonomic (e.g. García-Zepeda and Garduño-Monroy, 2006; Robles-Camacho et al., 2010), however, fossils were often recollected without following a systematic procedure, in which stratigraphic context and sedimentology were overlooked. The relationship between initial peopling and megafauna in the Mexican territory was also documented (Cruz-y-Cruz et al., 2015; ArroyoCabrales et al., 2006; Viñas-Vallverdú et al., 2015). More recently, the isotopic signatures and stratigraphy of these paleontological remains

Straulino L., Mainou, L., Pi, T., Sedov, S., López Corral, A., Santacruz Cano, R., Vicencio Castellanos, Alonso G., 2019, Approach to the knowledge of preservation of pleistocenic bone: The case of a Gomphothere cranium from the site of Tepeticpac, Tlaxcala, Mexico: Revista Mexicana de Ciencias Geológicas, v. 36, núm. 2, p. $170-182$. 
have been used as paleoenvironmental records (Pate et al., 1989; Wings, 2004; Robles-Camacho et al., 2010; Pérez-Crespo et al., 2012; Cruz-yCruz et al., 2016; Pérez-Crespo et al., 2016).

The in vivo bone structure is composed of an organic and inorganic fraction forming a complex material that provides flexibility and strength to the skeleton. The organic part is formed mainly by collagen. The inorganic, or mineralized, fraction is composed of microcrystalline bioapatite, always very similar in structure to hydroxylapatite but differing in composition by the substitution of carbonate for $\mathrm{PO}_{4}{ }^{3-}$ (biopatite in fresh bone can contain $7 \% \mathrm{wt} . \mathrm{CO}_{3}{ }^{2-}$ ), the presence of minor elements into lattice, and water incorporation (Wopenka and Pasteris, 2005).

During early diagenetic processes, the soft tissues are removed, collagen is degraded and mineralization, including chemical changes like fluor (F) enrichment and structural changes (e.g. cell parameters) transform bioapatite into a more thermodynamically stable phase. Apatite can incorporate a big number of chemical elements and the stoichiometric and perfect hexagonal structure is only possible for the structure of fluorapatite (Sponheimer and Lee-Thorp, 1999; Hedges, 2002; Jans, 2008).

Apatite is a mineral group with complex solid solutions. In order to simplify, the International Mineralogical Association (IMA) accepted minerals considering three end members: hydroxylapatite, fluorapatite and chlorapatite (Chang et al., 1996; Back, 2014). The different size of monovalent anions $\left(\mathrm{F}^{-}, \mathrm{Cl}^{-}, \mathrm{OH}^{-}\right)$determines a variation in cell parameters. The informal names francolite and dahllite have been applied for apatites enriched in $\mathrm{CO}_{2}$ and fluorine, and apatites enriched only in $\mathrm{CO}_{2}$, respectively (Deer et al., 2013).

The study of fossil diagenetic processes from neoformed and precipitated minerals in the vascular cavities of the bone and in the fractures allows to stablish the physical and chemical conditions that existed in the lithosphere during lithification, permineralization, and other fossilization processes (Casal et al., 2017). Thus, it is important to evaluate the conservation state, post mortem alteration and approximately estimate the impact of the transformations in its geochemical and isotopic signatures.

\section{DESCRIPTION OF THE STUDY AREA}

On May 2014, workers of the Tepeticpac Archaeological Project (TAP) of the Instituto Nacional de Antropología e Historia (INAH), accidentally uncovered around 10 centimeters of the distal section of a gomphothere tusk (Gomphotheriidae family). Afterwards, controlled excavations were undertaken using an archaeological exploration methodology in order to provide adequate stratigraphic information of local deposits. An area of four square meters was excavated using a horizontal grid made of four 1 x $1 \mathrm{~m}$ quadrants. Vertical depth was registered using a level bank placed over the deposits in the UTM coordinates: 0579830,2138859 , at an elevation of 2,298 meters above sea level (Figure 1). If we project the finding, coordinates in the interactive



Figure 1. Location Site. 
geological map published by Ferrari et al. (2018) we can verify that the location where the gomphotere cranium was found correspond to the unit described as: Volcano-Sedimentary and Lacustrine Deposits (Late Miocene to Pleistocene).

The discovery took place on an alluvial deposit exposed by a crosscutting road on the hillslopes of Tenextepetl hill, which is part of a mountain chain system that elevates around 300 meters above the Puebla-Tlaxcala valley and that separates the bottom of the valley to the south from the elevated Tlaxcala Block to the north.

The uppermost stratum was formed of 20 to 30 centimeters of loosened tepetate rock that had a steep north to south inclination, which matches the present day-slope surface. It contained no paleontological remains. Below the upper stratum lays Layer A, a colluvial stratum consisting of blocks of medium size blocks $(10$ to $20 \mathrm{~cm})$ of calcareous rocks and fragments of tepetate rock (fragipan-indurated tephra material). The deposit also had a north to south slope and a thickness of around 1 meter; it was strongly compacted, although some sand lenticular deposits were observed on the north and west profiles.

Below Layer A, on the north portion of the excavation, we detected Layer B, a deposit formed by the superimposition of several thin layers of fine to coarse rounded sands, some of them forming diagonal bands. These seemed to be part of alluvial or lacustrine deposits. In some sections, the sands were interspersed with thin layers of carbonates. The sand layers had grayish tones (10YR 6/1) and covered more than half of the excavation.

Layer $\mathrm{C}$ was the bottommost sediment. It is an alluvial stratum made up of medium to coarse rounded sands, probably corresponding to old lacustrine sequence, and very similar in composition to Layer B, but without carbonates. This layer extended throughout the excavation and had a very gentle inclination from north to south, discordant with the steep present day slope. It included dispersed concretions and small intrusions of Layer A materials, mainly calcareous rocks and medium size $(10$ to $20 \mathrm{~cm}$ ) blocks of tepetate rock, particularly near the east profile of the exploration.

Correlating the studied section with the complete PlioceneQuaternary paleosol-sedimentary sequence of Tlaxcala block (Sedov et al., 2009) we relate the B and C layers with the uppermost part of the uplifted Pliocene lacustrine sedimentary unit. Colluvial Layer A incorporates materials of the calcareous Pliocene lake deposits as well as fragments of Pleistocene tepetate. Six to eight layers of tepetate (indurated tephra) interlayered with paleosols formed during the middle and late Pleistocene constitute a semi-continuous mantle over the Tlaxcala Block (Heine and Schönhals, 1973; Sedov et al., 2009). As far as colluvial Layer A includes redeposited materials derived from both Pliocene (lacustrine) and Pleistocene (tephra-paleosol) units, we suppose that its development post-dates these units. We associate this colluviation with the phase of high geomorphic activity and intensification of surface erosion/sedimentation processes which occurred in the Central Mexican Highlands in the Terminal Pleistocene (late Glacial) (Heine, 1984; Sedov et al. 2009). This chronostratigraphic interpretation supposes a major time gap (hiatus) between formation of the Layer A and layers B and C.

Excavation of the skeletal remains was extremely difficult due to the compactness of the stratum, and by intrusive remnants of Layer A. At around 50 to 60 centimeters of excavation, we uncovered the top portion of the gomphothere cranium, which was comprised of the parietal, frontal and zygomatic bones, along with its intact right tusk and a partially looted left one. The cranium had its frontal bones upwards, and had an east-west orientation with its tusks pointing towards the west. Part of the front portion of the skull had collapsed due to the weight exerted by the upper layers. The tusks, maxillae and teeth were well-preserved. The rest of the cranium bones, especially the frontal bone, were fragile and fragmented due to compression because medium sized rocks that laid on top heavily smashed them. Some sections of the bones were absent such as portions of the zygomatic. Also, parts of the cranium bones were partially covered with a fine layer of clayish material of Layers A and B. It appears that sediments of Layer A incorporated and sealed the upper half of the fossil, while the lower section intruded into the underlying B and C layers (Figure 2).

\section{MATERIALS}

Three samples of bone where used for thin sections: a) Cortical bone and trabecular bone with crystalline minerals in the walls of the trabecula partially filled; b) Trabecular bone totally filled with sediments; c) Fractured trabecular bone cemented with the sediments of
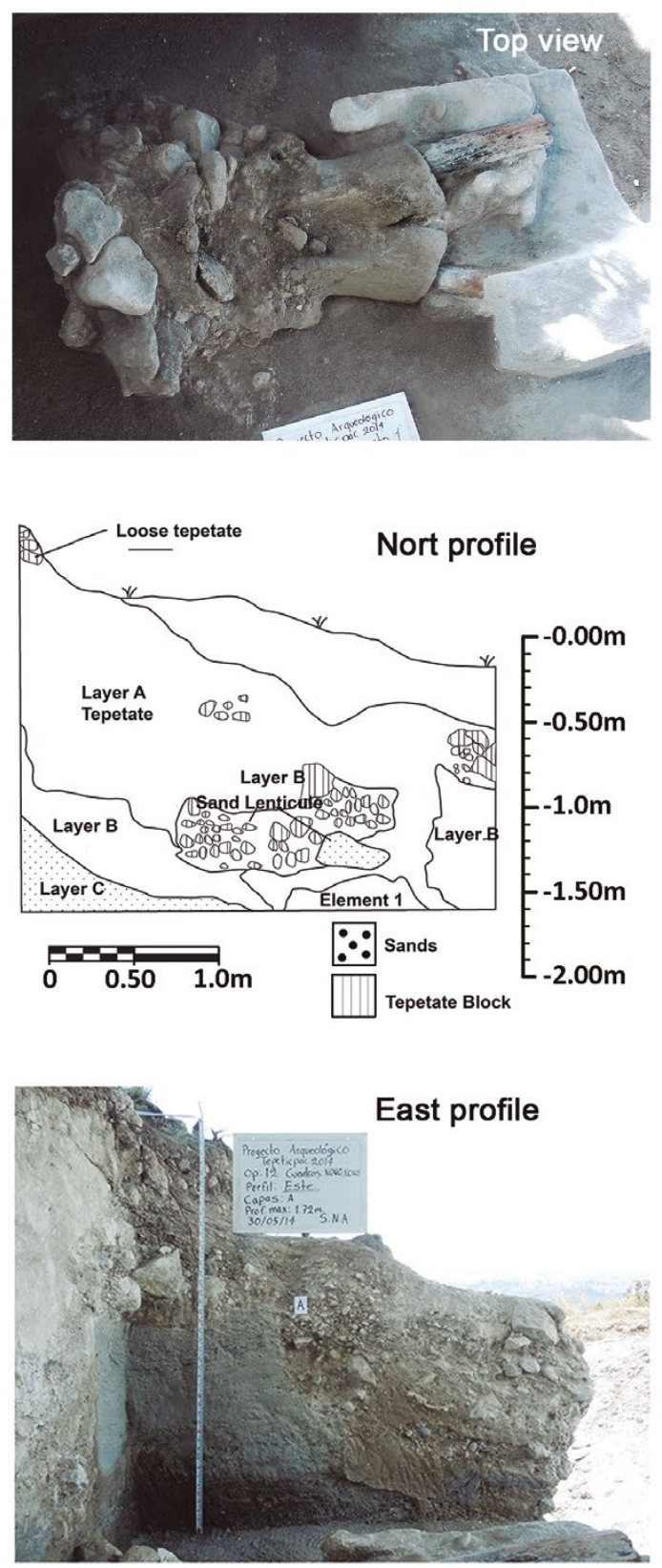

Figure 2. North and east profiles with a top view of the cranium. 

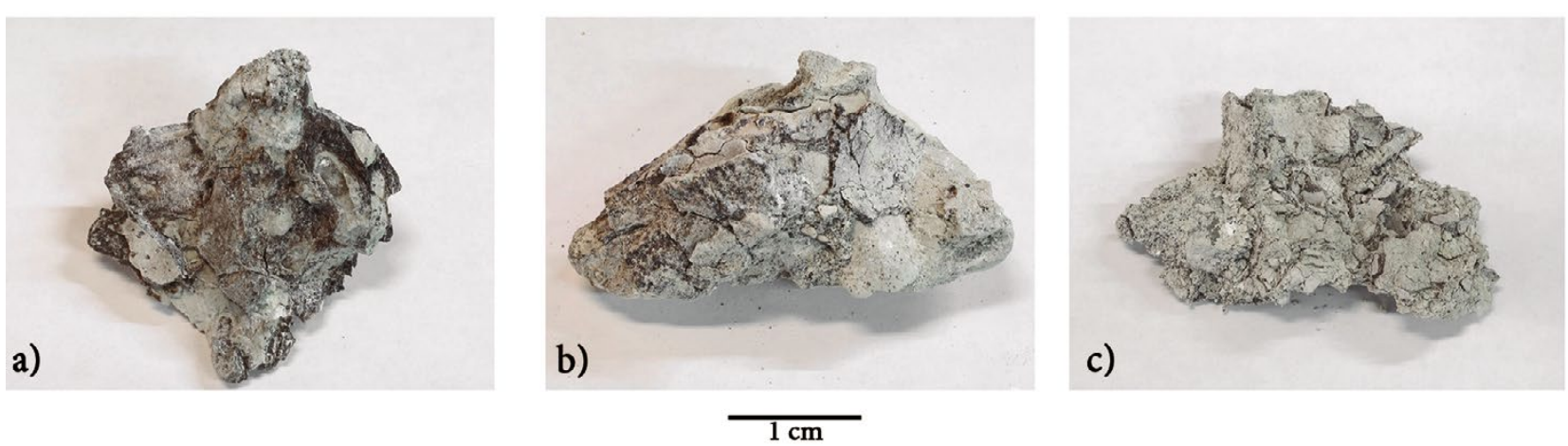

Figure 3. a) Cortical bone and trabecular bone with crystalline minerals in the walls of the trabecula partially filled. b) Trabecular bone totally filled with sediments. c) Fractured trabecular bone cemented with the sediments of the filling. We obtained two thin sections of each sample.

the filling (Figure 3). A total of six thin sections, two per sample were obtained, however, only one uncovered thin section from sample 2 was analyzed in SEM-EDS.

Samples of detached cortical bone, that was better conserved than the trabecular, were classified in three categories according to their anatomical position, color and porosity: 1 - frontal bone with a white yellowish color in the anterior face, the internal side of the cortical bone has a brownish color, they both have low porosity and diagenetic alterations such as pitting and delamination; the pittings and surfaces losses were filled with a white material; 2 - temporal bone with a brownish yellow color with more porosity and irregularities in the superficial area of the bone, the pores are filled with white and opaque mineral and with a translucent mineral. The internal face is black; 3- alveolus, the bone has a darker color and has more pores and other cavities which are filled with a white mineral. The internal face is black (Figure 4).

A detailed mineralogical study, using Powder X-ray Diffraction (PXRD) and Rietveld refinement, allow to characterized the differences between the tree categories to understand the permineralization of the bones and to identify the presence of diagenetic processes. For comparison purposes (Figure 5), we also use a pure inorganic well crystalized apatite (Cerro de Mercado, Durango fluorapatite), an actual bone of low crystallinity (cow bone composed by hydroxilapatite). We also measure with PDRX three samples associated with the sediments that covers the skeleton.

\section{METHODS}

\section{Petrography}

Thin sections allowed us to analyze the micromorphology of cortical and trabecular bone as well as the distribution and composition of subsequent layers of sediments. Histological analyses has been extensively used in archaeological and paleontological researches (Chinsamy and Raath, 1992; Hubert et al., 1996; Chinsamy, 1997; Jans, 2008; Lamm, 2007; Guido et al., 2012; Casal et al., 2017; Tomassini et al., 2015, Tomassini et al., 2014; Pfretzschner, 2004).

Cortical and trabecular bone with their sediment fillings were encapsulated, hardened and immobilized with a polyester resin applied with vacuum. Then the obtained blocks were cut with a diamond cutter until reaching almost $30 \mu \mathrm{m}$. The section is adhered to a sample carrier and then thin sections were polished by hand. An Olympus Bx51 petrographic microscope with digital camera attached and with several types of light (plain polarized light (ppl), cross polarized light $(\mathrm{xpl})$ and reflected light ( $\mathrm{rfl})$ ) was used. Analyses were performed using the Image Pro Puls 5.1 software.

\section{SEM/EDS}

Scanning Electron Microscopy along with an Energy Dispersive X-ray Spectroscopy (SEM - EDS) were used to relate the micromorphology of the bones and the chemical variability of the samples including some diagenetic features, such as tunneling, in the bone fragments surface (Hubert et al., 1996; Reiche et al., 2003; Guido et al., 2012).

Thin section of an uncovered sample 2 along with a non-treated sample in a transversal section of cortical bone were considered for this analysis. A JEOL JSM6060LV with an INCAEnergy 250 EDSLKIE250 were used, under the following parameters: $20 \mathrm{kv}$, vacuum, back scattered signal, and diverse magnifications.

\section{X-ray diffraction}

$\mathrm{X}$-ray diffraction (XRD) was used to determine the mineral composition of the bone, and to calculate several crystallographic parameters that help us to understand the bone mineral transformations, such as "crystallinity index", crystallite size, parameters $a$ and $c$ of unit cells and $\mathrm{CO}_{2}$ percentage (Person et al., 1995; Bocherens et al., 2008; Piga et al., 2009; Peters et al., 2000; Reiche et al., 2003; Keenan et al., 2015).

\section{Sample Preparation}

The bone samples were ground with an agate pestle and mortar to $<75 \mu \mathrm{m}$ and mounted in aluminum backside holders for X-ray powder diffraction analysis.

Clay Sample was gently disaggregated to avoid artificial grain size reduction of rock components, then was broken into small chips (2 $\mathrm{mm}$ ) using a porcelain crusher and subsequently dispersed in deionized water. Clay size fraction $(<2 \mu \mathrm{m})$ was separated in distilled water according to Stoke's law using the most unaggressive method (Moore and Reynolds, 1997).

From the $<2 \mu \mathrm{m}$ fraction, air-dried oriented preparation was obtained by pipetting some drops of the suspensions onto a glass slide, which was then dried at $30^{\circ} \mathrm{C}$ for a few hours (Moore and Reynolds, 1997). Ethylenglycol solvation of the slide was achieved by exposing them to ethylenglycol vapor at $70^{\circ} \mathrm{C}$ for a minimum of 12 hours.

\section{Measurement}

Measurements were carried out on a PANalytical Empyrean diffractometer equipped with a PIXcel3D detector and nickel filter, operating with an accelerating voltage of $45 \mathrm{kV}$ and a filament current of $40 \mathrm{~mA}$, using $\mathrm{Cu} \mathrm{Ka}$ radiation. All bone samples were measured over a $2 \theta$ angle range of $4-90^{\circ}$, with a step size of $0.02^{\circ}$ (2theta) and 40 s of scan step time.

Clay sample was examined by XRD in the air-dried form, saturated with ethylene glycol (EG) and after heating $\left(550^{\circ} \mathrm{C}\right)$. The preparations 

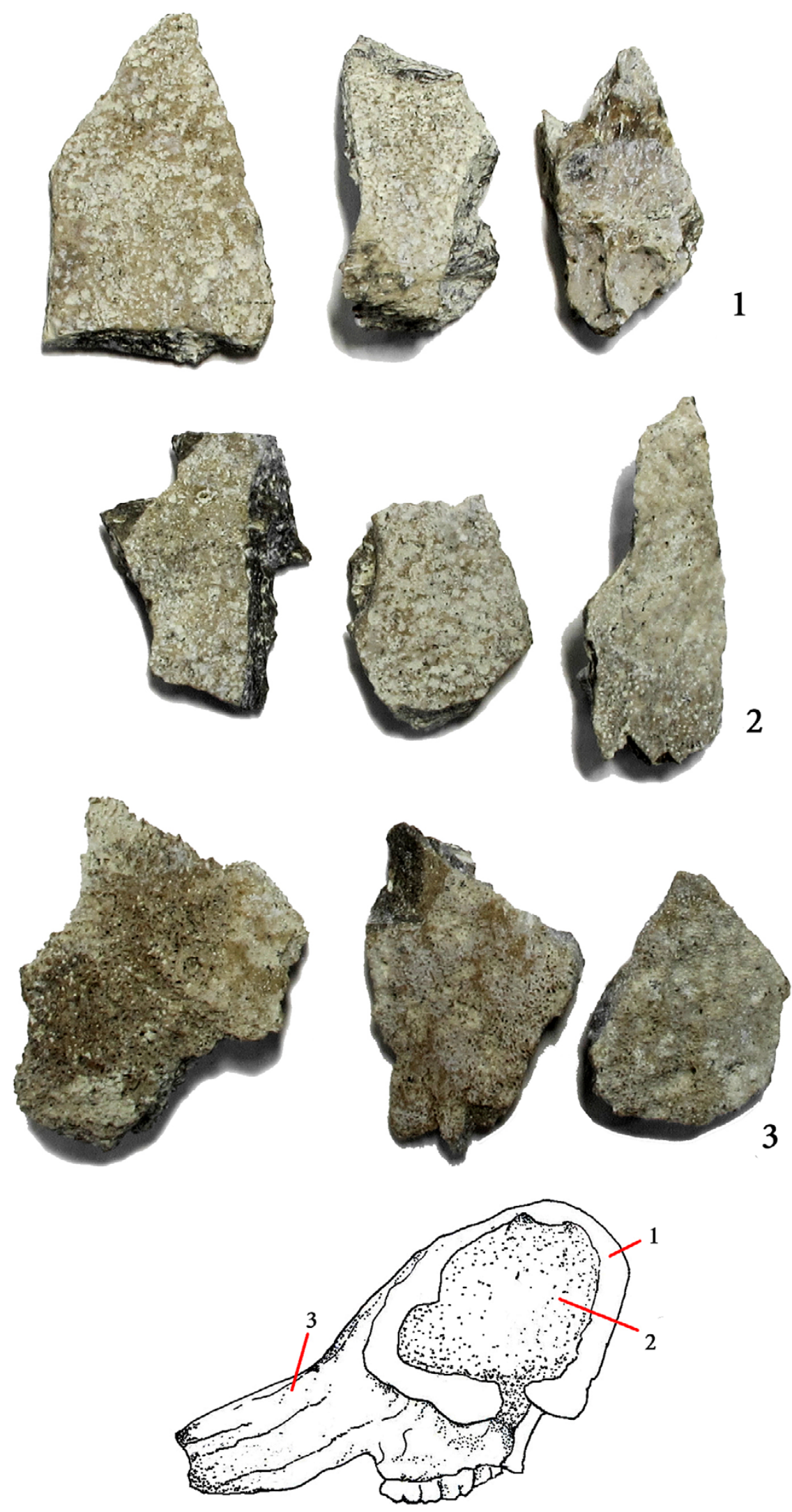

Figure 4. Cortical bone used for DRX, the sample sizes are no more than $3 \mathrm{~cm}$ long. 1) Less porous samples, 2) samples with medium porosity, 3) samples with the most porosity. 


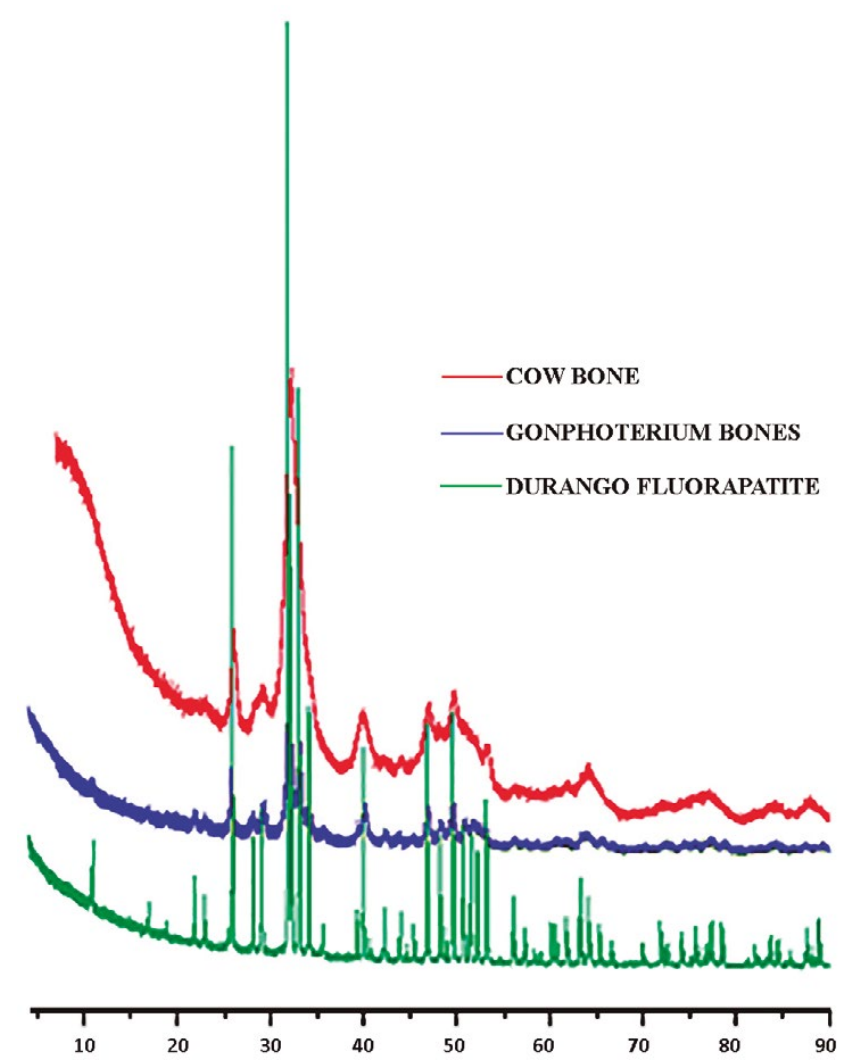

Figure 5. X-ray patterns of the Gomphoterium analyzed samples (blue) with intermediate crystallinity and the pure inorganic (Cerro de Mercado fluorapatite) and pure organic (cow bone hydroxilapatite) end members.

were measured over a $2 \theta$ angle range of $4-70^{\circ}$ (air-dried) and $4-30^{\circ}$ (glycolated and heated).

\section{Phase identification and characterization}

Rietveld refinement (Rietveld, 1967) was applied (using Highscore 4.5 PANalytical software) to calculate cell parameters and "XRD Crystallinity index" (Person et al., 1995). Crystallite size and $\mathrm{CO}_{2}$ content (O'Brien et al., 1990) were calculated to determine if the textural features observed in the petrographic study can be confirmed in a quantitative form using PXRD.

In $\mathrm{XRD}$ the degree of crystallinity is measured considering the separation of [202], [300], [211] and [112] reflections, located between $30^{\circ}$ and $35^{\circ}$ for a diffractogram measured using $\mathrm{KaCu}$ radiation (Bocherens, 1992). When the apatite is more crystalline, the separation between the peaks is bigger and the value of crystallinity index $\mathrm{CI}=\Sigma\{\mathrm{H}[202], \mathrm{H}[300], \mathrm{H}[112]\} / \mathrm{H}[211]=(\mathrm{a}+\mathrm{b}+\mathrm{c}) / \mathrm{h}$ ) increases (Person et al., 1995).

The mean size of the crystalline domains of bone carbonate hydroxylapatite crystals are measured employing Scherrer's equation:

$\mathrm{CS}=\mathrm{K} \lambda / \mathrm{B} \cos \theta$ (Klug and Alexander, 1974) where $\mathrm{K}$ is a dimensionless shape factor, with a value close to unity; $\lambda$ is the $X$-ray wavelength; $B$ is the line broadening at half the maximum intensity (after subtracting the instrumental line broadening), in radians.

A simple empirical equation to calculate the content of $\mathrm{CO}_{2}$ proposed by O'Brien et al. (1990) were used. This equation is based in the separation of the powder diffraction pattern of the 211 and 112 lines and it is expressed as: $w \mathrm{t} \% \mathrm{CO}_{2}=17.335-\left[615.524{ }^{*}(\mathrm{~d} 211-\mathrm{d} 112)\right]$.

\section{RESULTS}

\section{Thin sections and SEM/EDS}

Thin sections of cortical and cancellous (trabecular) bone showed the typical birefringence of phosphate minerals, such as apatite.

\section{Cortical bone}

The cortical bone retained the normal micromorphology of mammal bones; Haversian system, osteons with the concentric lamellae growing around the Haversian canals and osteocyte lacunae were observed as well as the interstitial lamellae (Figure 6); bone reabsorption can be seen in Figure 7b-1 (Lamm, 2007).

Nevertheless, there were a number of alterations within the cortical bone structure. Firstly mechanical damage was shown in a myriad of fissures all along the cortical bone with no preferential orientation; only the widest and most superficial ones had a micritic filling (Figure 7a).

The canals were, in general, filled with micrite (Figure $7 b-2$ ), and in few occasions with sparite (Figure $7 \mathrm{~b}-3$ ); the micritic filling exhibited stains of iron and manganese oxides.

The surfaces of the cortical bone fragments showed dissolution features such as tunnels with a rounded end (Figure 7c1, 7d-1); in an early state they were semi perpendicular to the surface and in a more developed state, they formed a network within a few tens of microns of the bone surface but sometimes within hundred microns. These cavities were interpreted as the result of selective enhanced dissolution at the areas with weaker/imperfect crystalline structure of phosphate fibers.

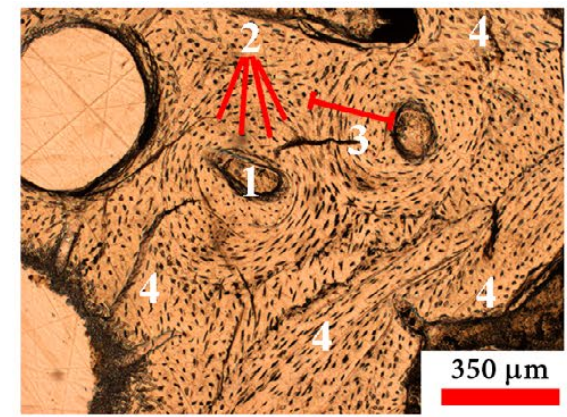

a)

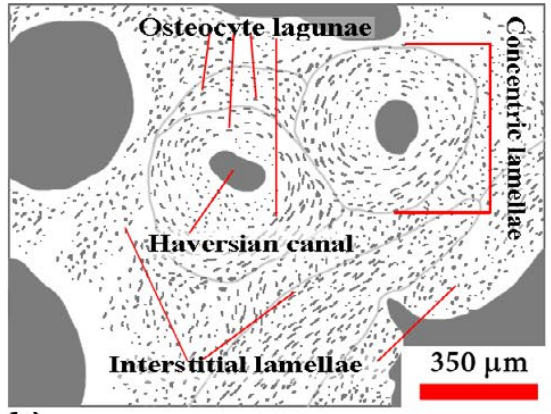

b)

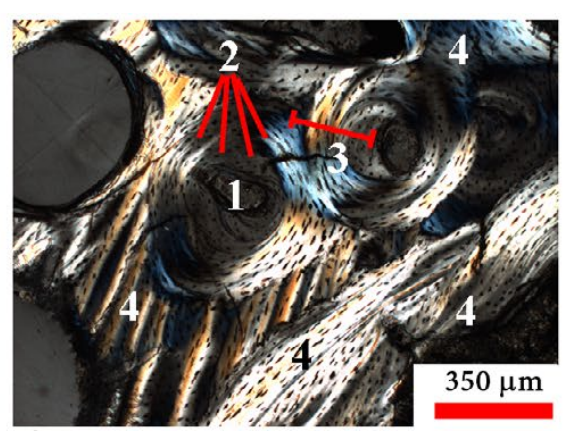

c)

Figure 6. a) Thin section of cortical bone under ppl; b) Diagram of cortical bone; c) Same section of cortical bone under xpl. In both micrographs the Haversian system (osteons) is seen: concentric lamellae (3) growing around the Haversian canals (1), osteocyte lacunae (2) are also visible as well as the interstitial lamellae (4). 


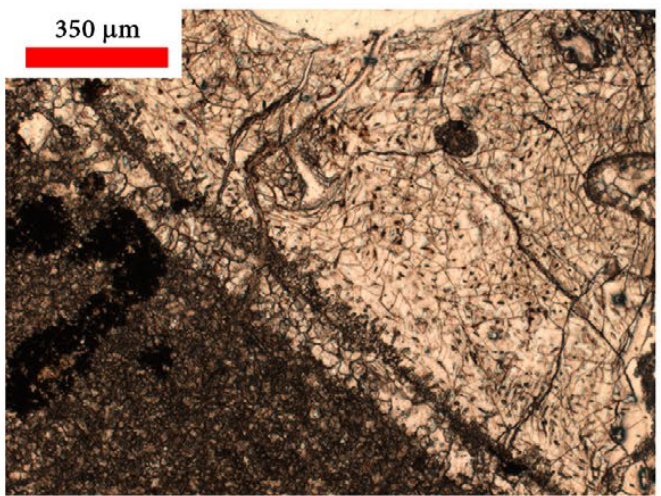

a)

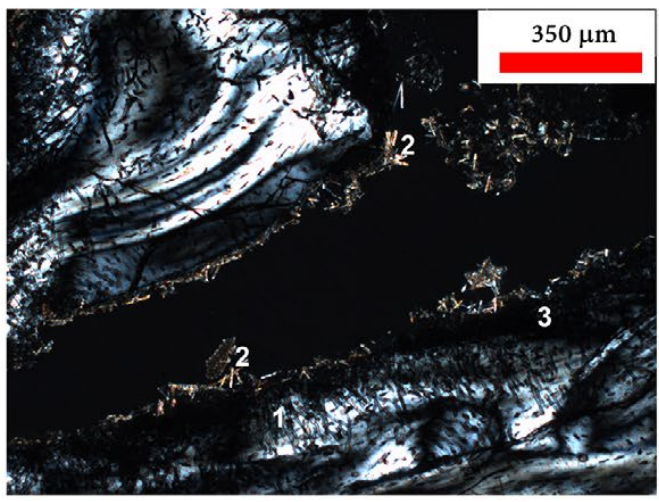

c)

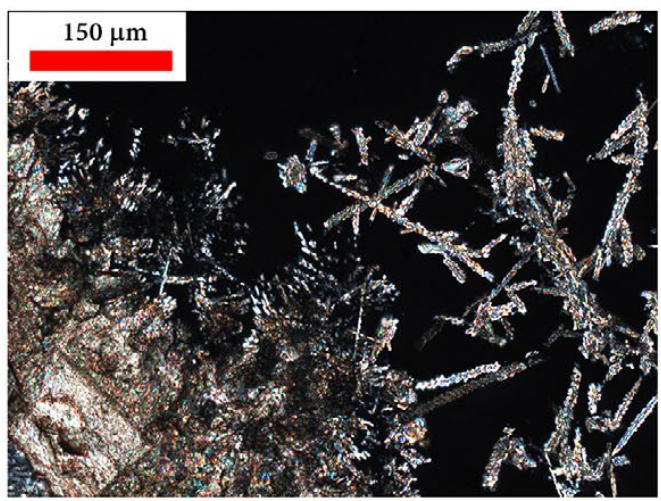

e)

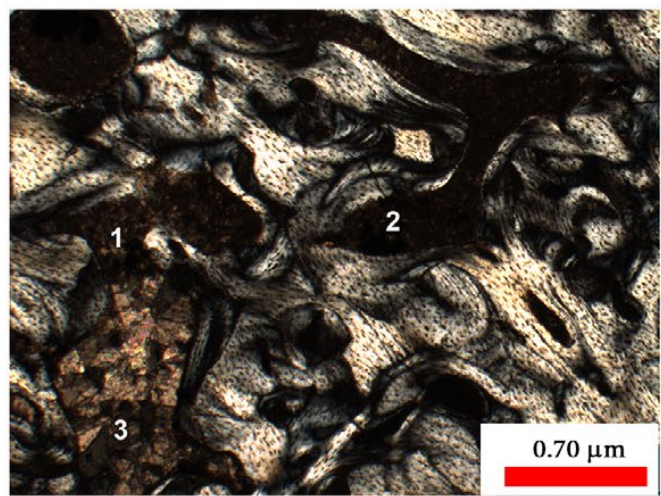

b)

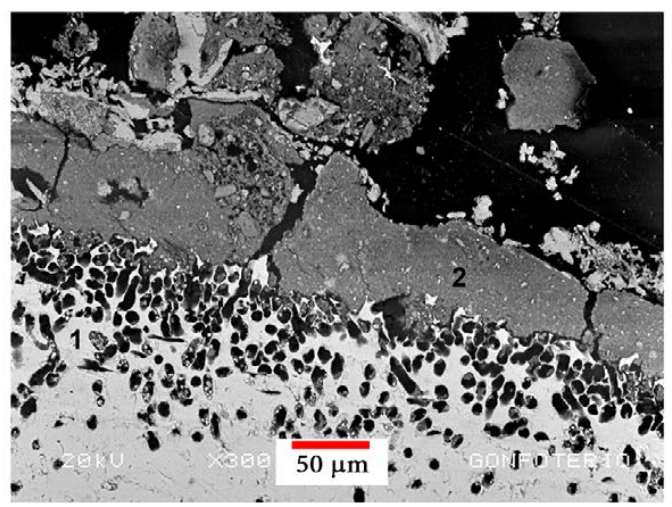

d)

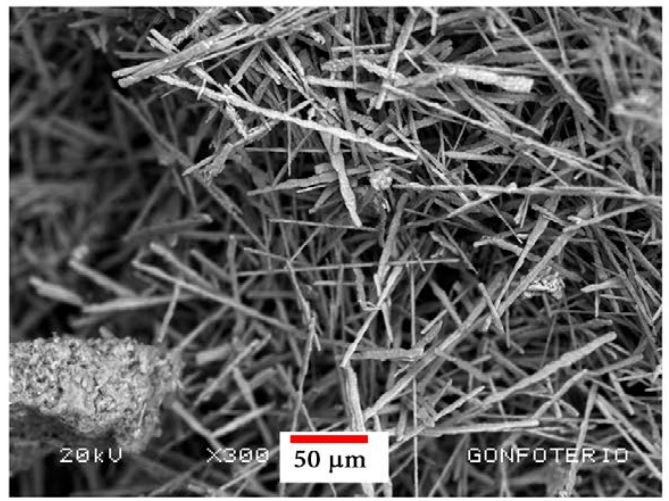

f)

Figure 7. Bone alterations. a) Fissures and fractures, only the wider fractures are filled; thin section (ppl). b) Thin section of cortical bone (xpl), 1) reabsorption of the bone visible in Haversian canals that have lost their oval shape, 2) canals filled with micrite, 3) canals filled partially with sparite. c) Thin section of the surface of cortical bone (xpl), 1) tunneling with a rounded end, 2) lublinite in surface, 3) micritized bone, the material have lost their birefringence. d) SEM micrograph of thin section of cortical bone, 1) tunneling with rounded ends, 2) layer with different composition of the bone, not all the tunnels are filled. e) lublinite, thin section (xpl). f) Lublinite, SEM micrograph.

Thin sections showed a material with no birefringence in the surface area of the sampled bones composed mainly of $\mathrm{Si}, \mathrm{Al}, \mathrm{O}, \mathrm{Mg}, \mathrm{Fe}$, and $\mathrm{K}$ (Figure $7 \mathrm{c}-3$ and Figure 8), over this layer a micritic one can be found. At the surfaces that exhibited the tunneling, but not the layer of minerals without birefringence, the voids have been filled with micrite.

These areas of dissolved bone with outer layers of calcium carbonate had rather similar morphology to that of lublinite -needle fiber calcite (Figure 7c-2). This lublinite is formed by polycrystalline chains, composed of calcite rhombohedrum joined together with a P3 Morphology of Verrechia and Verrechia (1994) (Figure 7e and 7f).

\section{Cancellous bone}

The morphology of the cancellous bone was also conserved. Parallel lamellae with a plywood structure was visible despite the great amount of fissures and fractures in this type of bone (Figure 9a).

The voids between the walls of the trabecula were filled with specific layers, first a micritic one deposited directly over the surface of the bone (see bottom of figure 9c), then a sparitic layer with big and defined crystals that is the last one (Figure $9 \mathrm{~b}$ ).

When the spaces were filled, after the sparitic layer there was another micritic filling (Figure 9a) and a sandy mixture of minerals and 


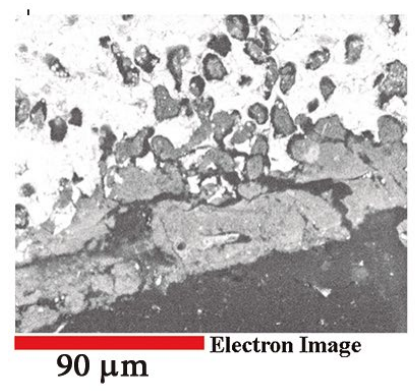

Figure 8. SEM image and mapping elements. It can be seen that the filling and layer over the bone is composed mainly of silicon, aluminium, and some oxygen, magnesium, iron and, potassium.

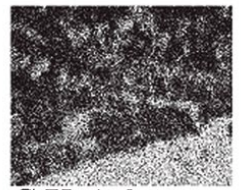

C Ka1 2

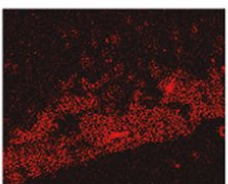

Si Ka1

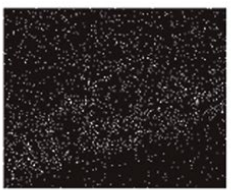

Fe Ka1

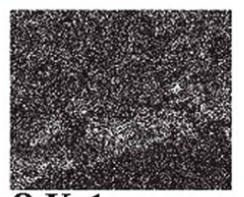

O Ka1

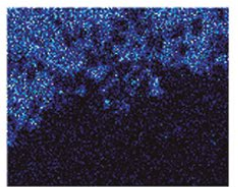

P Ka1

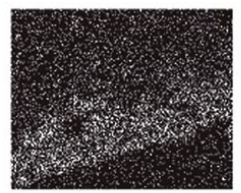

Al Ka1

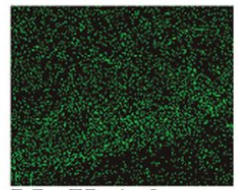

Mg Ka1_2

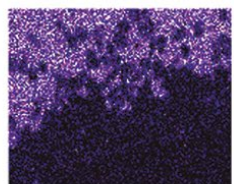

Ca Ka1

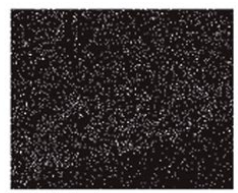

K Ka1 volcanic rocks cemented with micrite or sparite. The minerals in the sand were identified as plagioclase, bone fragments, sparite with the signs of etching, amphiboles, quartz and volcanic glass (Figure 10); we also found a great amount of clays and phytoliths.

When the micritic filling had fractures or pores with a large surface, the spaces were filled with sparite.

\section{$X$ ray diffraction}

For all the 10 measured bone samples (three aliquots of every type and one duplicate) the peak positions and Miller indexes corresponded to the carbonate-apatite card ICDD 01-073-9696 and general formula: $\mathrm{Ca}_{5}\left[\left(\mathrm{PO}_{4}\right)^{3-} \mathrm{x}\left(\mathrm{CO}_{3} \mathrm{~F}\right) \mathrm{x}\right](\mathrm{F}, \mathrm{OH}, \mathrm{Cl})$. This structure was used in all the samples in which the Rietveld refinement has been applied. The quantitati ve results of $a$ and $c$ cell parameters, crystallinity index (CI-DRX), crystallite size $(\mathrm{CZ})$ and $\mathrm{wt} \% \mathrm{CO}_{2}$, can be seen in Table 1 and Figures 11,12 and 13. The rwp agreement index for the adjustment of all the samples ranges from 4.8 to $7.0 \%$.

During the Rietveld refinement for two samples of group 3, $0.9 \%$ and $1.1 \%$ of smectite clay minerals and less than $1 \%$ of quartz (in 1 sample) were found. These features are indicative of detrital minerals filling porosity and cavities. The sediments were composed of calcite, quartz, plagioclase and kaolinitic and smectitic clay minerals.

The clay mineralogy $(<2 \mu \mathrm{m})$ of sediments was composed predominantly of smectite with a small presence of kaolinite. The smectite was confirmed by a strong (001) reflection at about $14 \AA$ in air-dried condition that shifted to about $17 \AA$ in ethylene glycol treated samples and collapsed to $10 \AA$ after heating at $550{ }^{\circ} \mathrm{C}$. The presence of pure smectite (without mixed layers) demonstrates that the diagenetic process that affected the fossil bones was incipient and always bellow $100^{\circ} \mathrm{C}$ because this clays begins to transform over these temperatures.

There is a clear correlation between "crystallinity index" and $a$ cell parameter as well as between "crystallite index" and $\mathrm{CO}_{2}$ content in the carbonate hydroxylapatite (Figures 12 and 13). Samples crystallite size ranged from 370 to $555 \mathrm{~nm}$ (with the exception of sample 3.2) in the range reported as the largest dimensions for bones (Glimcher, 1984) confirming the preservation of bone, but smaller than the parameter calculates for geological Cerro del Mercado apatite $(1,568 \mathrm{~nm})$. For all the analyzed samples, $a$ lattice parameter variations ranged $(9.344 \AA$ to $9.357 \AA$ ) exceed the variations of $c$ parameter $(6.896 \AA-6.899 \AA)$.

The aliquots of sample number 3 have small $a$ cell parameter values, more amount of $\mathrm{CO}_{2}$ and smaller crystallinity index.

\section{DISCUSSION}

The transformation in the bone minerals has proceeded in such manner that the paleohistological structure is well preserved. Hubert et al. (1996) proposed that when collagen is removed from the structure a)

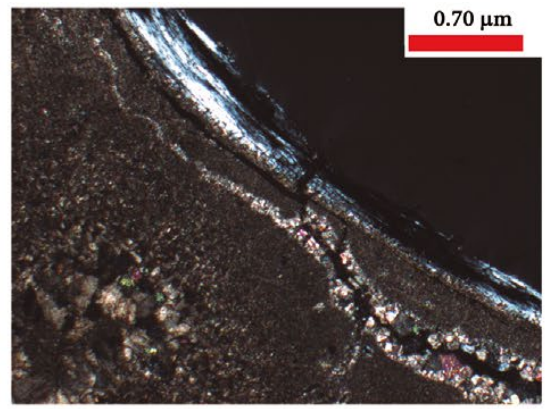

b)

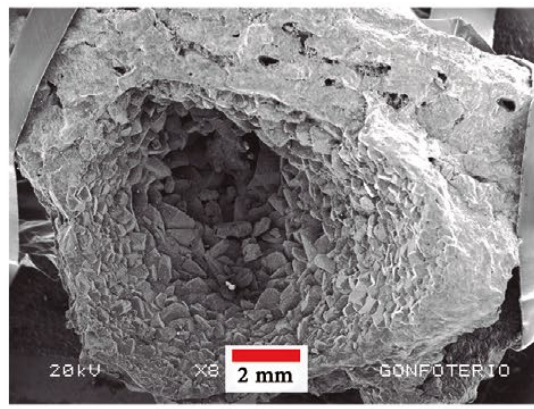

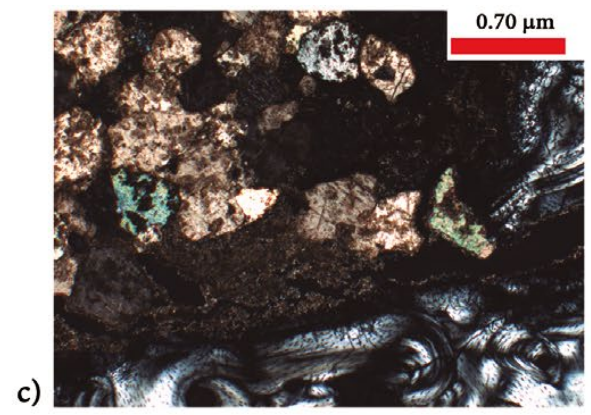

Figure 9. a) Trabecular bone with parallel lamellae and several fissures, the filling consist in a micritic layer with sparitic recrystallization in fractures and other areas, thin sections (xpl). b) SEM image of the crystalline sparitic layer in spaces not completely filled. c) Bone with layer without birefringence, layer of micrite and then sparitic cement, thin section (xpl). 

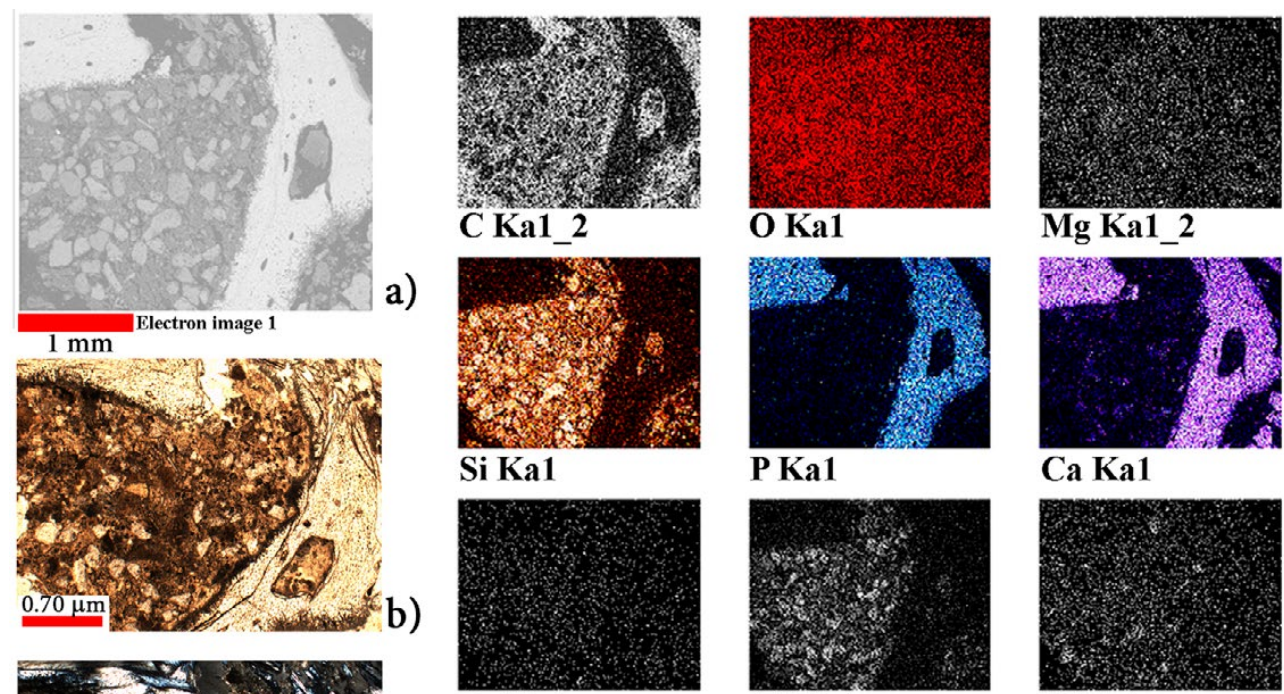

P Ka1
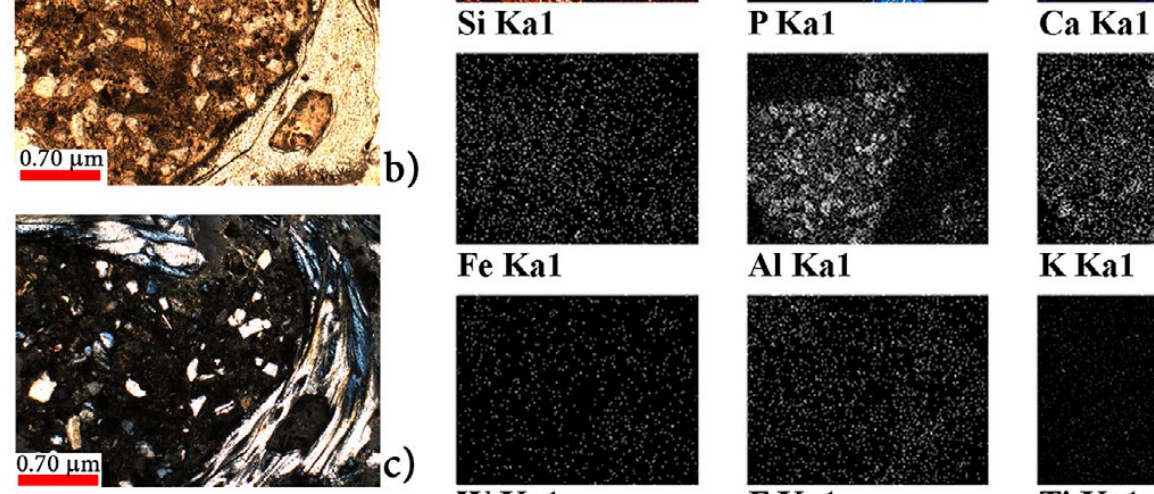

Fe Ka1

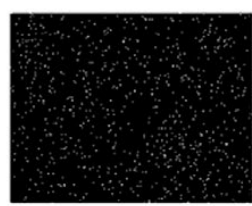

W Ka1

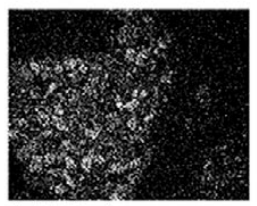

Al Ka1

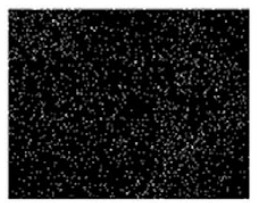

F Ka1

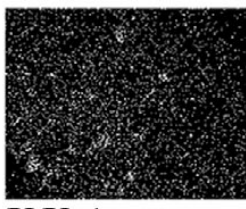

K Ka1

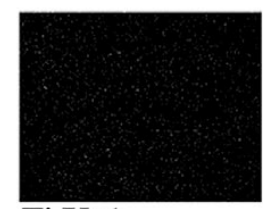

Ti Ka1

Figure 10. Volcanic sand and its elemental composition. a) SEM image of the thin section with a fragment of bone and sand filling. b)Same area in thin section (ppl). c) Same area with cross-polarized light (xpl). At right, we can see the elemental mapping; the volcanic sand fraction is composed mainly by silicium, aluminium and oxygen, with other elements such as magnesium, calcium, iron, potassium.

the bone does not turn into a disorganized mass but the apatite grows on crystal seed preserving the orientation of original crystals and thus preserving micron scale features. Apatite growth stops when the pores and surface of the bone is sealed, in this case, with the calcite layers and clay coatings, and calcite and detrital minerals infillings. The biogenic hydroxylapatite reacted easily with soils and sediments because of its small size and large surface area.

Despite the well-preserved microstructure of the bone, changes in the mineral lattice has been noted on the XRD analysis: the mineralized bone has changed from bioapatite (carbonated form of a non-stoichiometric hydroxylapatite) to carbonate-apatite (e.g. card ICDD 01-073-9696) and exhibits higher "crystallinity index", -smaller a cell parameter than the bioapatite phase characteristic of bones in vivo-. Person et al. (1995) stablished that the increase in crystallinity in fossil bones is more related to taphonomic conditions than to the geological age, and that the same variations of crystallinity are found in archaeological and in paleontological bones, which suggests that the increase in crystallinity occurs in the earliest stages of diagenesis.

This mineral transformation can be described as a dissolution-recrystallization process related with decrease in the hydroxyl-ion content (Newesly, 1989). The transformation that preserves the external appearance of the bone was described as a stepwise (isomorphous exchange) non equilibrium transition (Lucas and Prévôt, 1991) which is more efficient in porous bone like the one observed in our sample 3. Smaller

Table 1. XRD values for all the apatite samples: $a$ and $c$ cell parameters (including error) obtained by Rietveld refinement ( $r w p$ : agreement index for the adjustment), calculated wt $\% \mathrm{CO}_{2}$ (O'Brien et al. 1992 ), crystallinity index (CI), and crystal size (CZ, by the Scherrer Equation). DgoApa: mineral apatite from Durango; Cow Bone: fresh bone from a cow.

\begin{tabular}{lllllcc}
\hline Sample & $\boldsymbol{a}(\AA)$ & $\boldsymbol{c}(\AA)$ & $\mathbf{w t}$ \% $\mathbf{C O}_{2}$ & $\mathbf{C I}$ & $\mathbf{C Z}(\mathbf{n m})$ & $\boldsymbol{r} \boldsymbol{w} \boldsymbol{p}(\%)$ \\
\hline 1.1 & $9.3561(7)$ & $6.8989(5)$ & 2.9 & 0.458 & 410 & 6.37 \\
1.2 & $9.3555(8)$ & $6.8975(5)$ & 3.17 & 0.434 & 369 & 6.42 \\
1.3 & $9.3577(7)$ & $6.8976(5)$ & 2.95 & 0.44 & 463 & 5.94 \\
2.1 & $9.3546(7)$ & $6.8973(4)$ & 3.21 & 0.405 & 554 & 6.02 \\
2.2 & $9.3541(8)$ & $6.8967(5)$ & 3.2 & 0.392 & 414 & 5.48 \\
2.3 & $9.3568(7)$ & $6.8975(4)$ & 3.21 & 0.425 & 433 & 5.88 \\
3.1 & $9.3471(3)$ & $6.8958(3)$ & 7.9 & 0.375 & 412 & 5.63 \\
3.2 & $9.344(3)$ & $6.896(4)$ & 7.9 & 0.375 & 482 & 6.07 \\
3.3 & $9.3504(6)$ & $6.8959(4)$ & 3.5 & 0.372 & 239 & 6.33 \\
DgoApa & $9.3925(4)$ & $6.8831(2)$ & 0 & 1.25 & 1568 & 4.86 \\
CowBone & $9.424(1)$ & $6.8922(9)$ & 2.8 & 0.1 & 88 & 7.01 \\
\hline
\end{tabular}




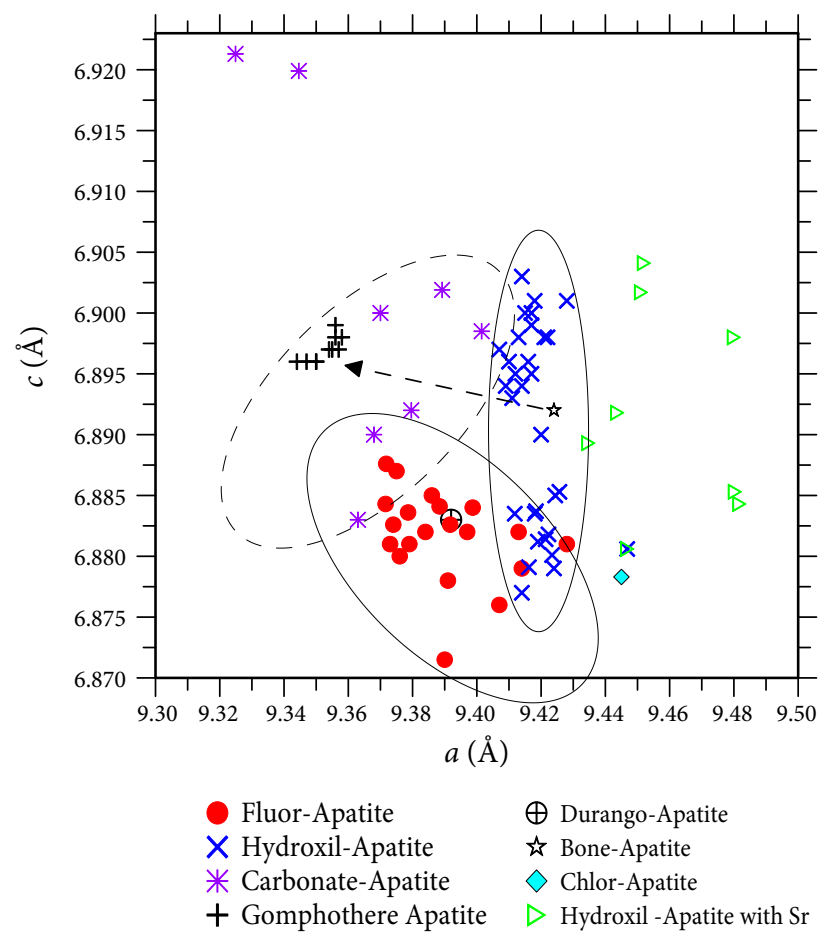

Figure 11. $a(\AA)$ and $c(\AA)$ lattice parameters calculate by Rietveld refinement of the apatite identified in the gomphotere cortical bone fragments (samples 1 , 2 and 3$)$ in comparison with $a(\AA)$ and $c(\AA)$ lattice parameters of the principal different apatite types reported in the literature. The cell parameters of the apatite used for comparative purposes were taken from the international databases of the ICSD (Inorganic Crystal Structure Database) and ICDD (International Center for Diffraction Data). The arrow indicates the process of post-mortem mineralogical transformation. Typical the fluorapatite is the preserved mineral in fossil bones (Wopenka et al 2005) and fluorine proceeds from the interaction between water-soil and sediments.

a cell values in sample 3 were related with further transformation of biogenic hydroxylapatite. The end member of this transformation in a complete fossilization process would be an almost pure fluorapatite as observed in Figure 11 -taken from ICSD (Inorganic Crystal Structure Database) and ICDD (International Center for Diffraction Data) XRD database for a comparative purpose-.

This reduction of the $a$ lattice parameter can be observed (Figure 11) for all the analyzed samples by comparison with power diffraction files (ICSD and ICDD) of pure hydroxylapatite.

Apatite has a hexagonal $(\mathrm{P} 63 / \mathrm{m})$ structure $(a=9.4-9.6, c=6.8$ to $6.9 \AA)$ with two metal cation sites, a tetrahedral (T) site $\left(\mathrm{PO}_{4}{ }^{3-}\right)$ and an anion column where it is possible to find $\mathrm{OH}^{-}, \mathrm{F}^{-}$and $\mathrm{Cl}^{-}$. The carbonate ion can substitute two places in the mineral structure: it can be found at anion column or can substitute phosphate ion at the T site (Hughes and Rakovan, 2015; Wopenka and Pasteris, 2005).

The carbonate in the apatite lattice structure could proceed from neoformed calcite -the main filling mineral in the vascular system of bones and in the voids of the trabecular bone. The calcitic permineralization of bone by micritic precipitation is relatively frequent and it is an usual phenomenon in the fossil record (Fernández López, 1999); field observations in archaeological sites show that bones are generally preserved when they co-exist with calcite in the sediments (Berna et al., 2004).

The carbonate-apatite mineral phase in the skull bone has a negative correlation between "crystallinity index" and $\mathrm{CO}_{2}$ amount and $a$ cell parameter (Figures 12 and 13). Carbonate has the effect of making the apatite less crystalline (e.g. Nemliher et al., 2004). In the studied samples it can be prove this as an indirect relationship between $\mathrm{CO}_{2}$ content and "crystallinity index" (Figure 13). Sample 3 is enriched in $\mathrm{CO}_{2}$ and because of that it is less crystalline and has a smaller crystallite size value. Carbonate in apatite constrains the crystallinity to nanometric scale and gomfotherium fragments have quite big size values of crystallite. Therefore, we suggested a partial isomorphous exchange of carbonate by fluorine in apatite as a result of the diagenetic processes.

Higher crystallinity and stability in the samples with low content of $\mathrm{CO}_{3}{ }^{2-}$, is related to the fact that $\mathrm{Ca}-\mathrm{PO}_{4}{ }^{3-}$ bond is stronger than the $\mathrm{Ca}-\mathrm{CO}_{3}{ }^{2-}$ bond, determining higher solubility of carbonate-containing apatite compared to carbonate-free apatite, thus making the carbonated apatite more susceptible to acid dissolution (Wopenka and Pasteris, 2005).

\section{Secondary features of bone and neoformation of secondary minerals}

The presence of the tunneling in the surface of the bone suggests bioerosion due to fungus or cyanobacteria attacks. The term bioerosion is applied to the characteristic destruction of histology, accompanied by an increase of porosity caused by microorganisms in the depositional environment (Turner-Walker and Jans, 2008).

Trueman and Martill (2002) showed that a great amount of fossil bones are affected by bioerosion despite the previous assumption that fossil bones are unaffected by it. The features found in the bones are described as Type 1 Weld tunneling.

Weld described microbial attack on mineralized tissue in 1864 . He found tunnels ranging from 5 to $10 \mu \mathrm{m}$ and under electron microscopy appeared empty with well-defined calcification walls. Hackett (1981) describes thoroughly the Weld tunneling as remarkably uniform in

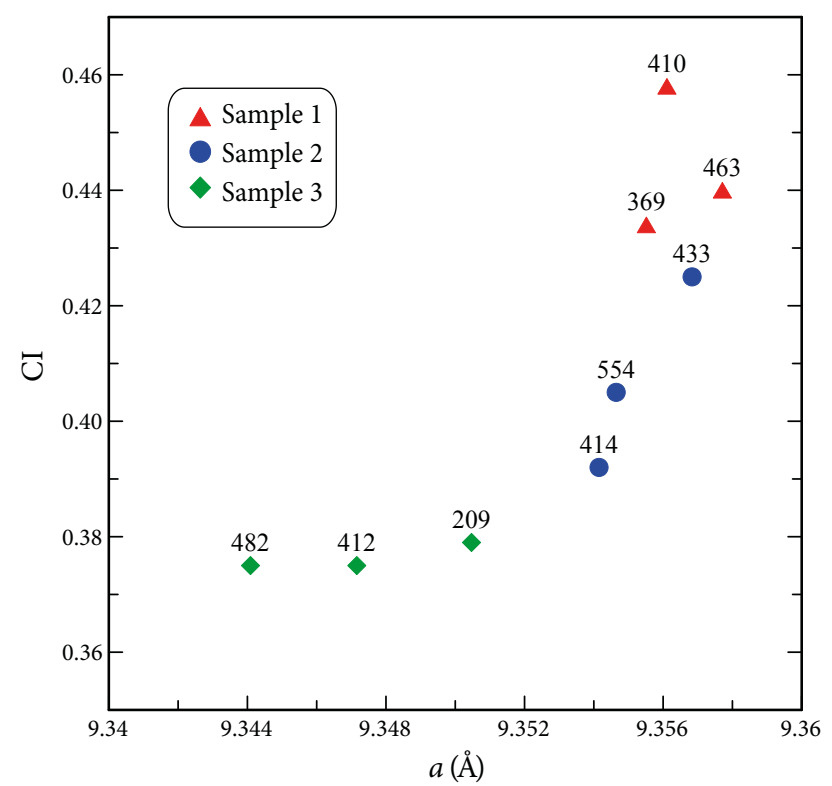

Figure12 . Relationship between the Crystallinity Index (CI; Person et al., 1995) and the $a(\AA)$ cell parameter for the different aliquots of the three samples of cortical bone. The labels correspond to the crystallite size. It can be observed that number 1 is the bone with the highest crystallinity and the best preserved. Bone number 3 (which probably was the most porous at origin) is the one that mineralogically was more transformed (lower value of $a(\AA)$ cell parameter) but has a lower crystallinity index and is slightly less preserved. 


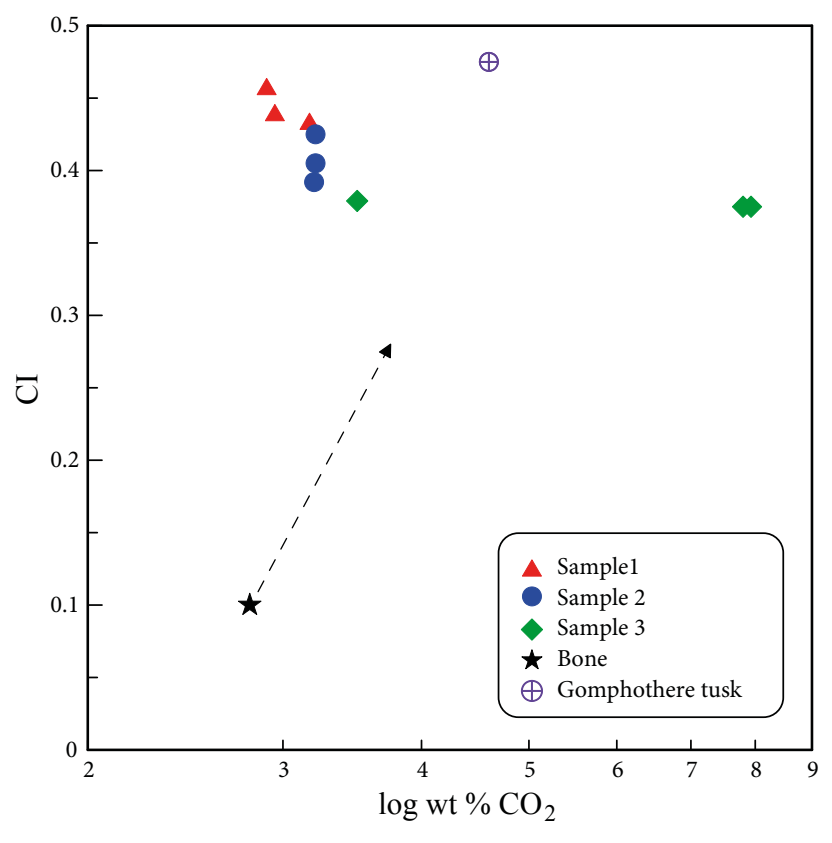

Figure13. Relationship between the Crystallinity Index (CI) and the $\mathrm{CO}_{2}$ amount (O'Brien et al., 1990) for the different aliquots of the three samples of cortical bone and actual bone. It can be observed that number 1 is the bone with the highest crystallinity index and the lowest $\mathrm{CO}_{2}$ content. The arrow indicates the general process of post-mortem mineralogical transformation.

diameter, always passing away from the surfaces of the cortex and the osteon canals; also, their curse is never smooth, straight nor longitudinal between its main features. The tunneling in the samples fulfilled all of these features (see figure $2 \mathrm{a}$ and $3 \mathrm{~b}$ of Turner-Walker and Jans 2008, figure 1 and 2 on Jans, 2008; figure 2a on Trueman and Martill 2002, figure 2 and 3 of Hackett 1981 and compare to Figures 7 c y $7 d$ here).

It is not rare to found Weld tunneling in the samples because it is by far the most common type of bioerosion (Trueman and Martill, 2002) and it is usually found in animal bones (Jans et al., 2004). Fungal attack is the recognized cause for this type of tunneling but also has remarkable similarities to those made by endolithic filamentous cyanobacteria; despite being phototrophic, the cyanobacteria can thrive in environments with extremely low light levels (Turner-Walker and Jans, 2008).

Jans (2008) showed that the fungal hyphae contained minerals in solution within them, while the tunnels do not have any redeposited mineral; this indicates that the dissolved apatite is transported out of the bone as shown in the micrographs of Figures $7 \mathrm{c}$ and $7 \mathrm{~d}$. It is not clear if fungi dissolve the bone to harvest nutrients or as a medium; as well the tunneling caused by cyanobacteria does not show redeposited minerals.

Cyanobacteria depend on light, so the surface of the bone will be exposed to dissolution only until the bone is covered with sediments. On the other hand, fungus can grow and thrive without light and the attack could have taken place in almost every stage before the bone was entirely sealed.

It is not possible to know if the attack was due to cyanobacteria or to fungus so we cannot establish if the biological attack of the skull was in early times prior to its burial or when it was buried with sediments. However, the probability of strong biogenic alteration of bone after burial seems to be rather low, because the sediments of Layer A have very weak signs of pedogenetic and biological processes other than carbonate migration. Only fragments of tepetate rock show features of pedogenesis, regardless of their redeposition and not indicative of soil formation at the site. Therefore, the possibility of bone weathering and phosphate mineral alteration on the surface before incorporation into colluvial stratum is rather high.

In addition, the process of bioerosion is suggested by the presence of needle fiber calcite in the micritic layer directly over the surface of the bone. This mineral suggests weathering due to direct or indirect biological agents and with morphology changes due to physicochemical processes (Verrecchia and Verrecchia, 1994; Becz-Deák et al., 1997; Khokhlova et al., 2001; Bajnóczi and Kovács-Kis, 2006; Durand et al., 2010; Straulino et al., 2013).

The neoformation of various secondary minerals within the pore space of the bone, as well as the transformation of the primary mineral components of bone, are related to a set of processes. These processes comprise the transformation of the primary structure, composition of bone tissue, deposition of minerals and the neoformation of various secondary minerals in the surface and porous structure of the cortical bone and in the voids of the trabecular bone.

A relative chronology and succession of the processes according to the relative position of minerals on microscale is proposed below:

Collagens loss. Isotopes analysis showed $\mathrm{N}$ value of cero and $13 \mathrm{C}$ value of -26.3 , which indicates that the carbon is from an external source (Cienfuegos-Alvarado and Pérez-Crespo pers. com.)

Heterogeneous mineral transformation of the bone hydroxylapatite.

Partial dissolution of phosphates in the cortical bone surface as shown in figures $7 \mathrm{c}$ and $7 \mathrm{~d}$ that seems to be related with microorganisms.

Precipitation of clay suspensions. The layer immediately over the bone composed of $\mathrm{Si}, \mathrm{Al}, \mathrm{O}, \mathrm{Mg}$, was identified as a clay with no birefringence; blocks of oriented clays in the trabecular bone were identified. With XRD, the clay was identified as smectite and some kaolinite. It is also important to point out that the presence of pure smectite confirms that the diagenesis was minimum.

Precipitation and crystallization of secondary calcite in the bone voids: a) quick precipitation of micrite, b) slower crystallization of sparite in fissures and voids. Precipitation of fine layer of micrite in the bone surface and its transformations to needle fiber calcite (lublinite).

Deposition of sand particles such as volcanic rocks, plagioclase, bone fragments, etched sparite, amphiboles, quartz and volcanic glass. Secondary calcite precipitation at the same time.

The trabecular bone exhibits a bad state of preservation mainly due to physical causes (it is substantially fragmented and fissured). The presence of smectite in the voids of trabecular bone (see section 5.2) could lead to the expansion of this clay causing stress in the bone and consecutively the release of this stress by the fragmentation of the bone.

Types and chronology of these processes in the Cuenca Alta of Tlaxcala could be related to the pedogenetic processes that developed in the sediments; however, the sediments of the site are currently in analysis.

On the other hand, similar progressions have been studied in detail in the key sections of the Tlaxcalan localities of Tlalpan and Mamut (Sedov et al., 2009) where it was shown that weathering, clay neoformation and clay illuviation took place in the late Pleistocene (MIS3-2), whereas neoformation of carbonates occurred predominantly in the Holocene. It is possible that such succession is valid also for the studied mineralization processes.

\section{Implications in different areas}

The paleoclimatic implications point out that the weathering, microbial transformations, and clay illuviation are indicators of humid climate; while carbonate depositions evidence aridization.

Secondary carbonates and layers of clays seal the bone surface and thus prevent further deterioration promoting the preservation of the bone. 
Implication for the geochemical records implies that secondary carbonates not only precipitate on the bone and teeth surface, but also penetrate pores and fractures; thus they could influence chemical and isotopic composition of the bone samples altering the geochemical record of past environment.

\section{CONCLUSIONS}

Bone paleohistological structure is well preserved; however, the cortical bone is more preserved that the cancellous bone because the clays that fill the trabecula macroporosity generated internal stresses that fragmented the bone walls.

Nevertheless, the bone composition changed; there is no collagen and there is exogenous $\mathrm{C}$; the mineral part of the bone also was transformed from carbonate non-stoichiometric hydroxylapatite to more crystalline apatite- probably fluorine-carbonate apatite. These changes imply a more stable and less soluble mineral than that of the original bone.

The exogenous carbon detected with isotopical analysis and the carbonate phase in the carbonate-apatite could proceed from the calcite, the main filling mineral. The permineralization of bone by calcite is frequent and enhance the bone preservation.

Biological activity was detected by dissolution and structure modification of the bone surface and the transformation of micrite to needle fiber calcite.

With the calcite infilling we also observed clays, pure smectite and kaolinite, which could be the first minerals intruding the bone macroporosity and deposited in the bone surface. Furthermore, we found sand filling composed of quarts, feldspars, amphiboles and volcanic glass, with a clear different origin if compared with the clays and the calcite.

\section{ACKNOWLEDGEMENTS}

The research was supported by PAPIIT, project IN106616 Paleoecología, transformación biótica y desarrollo cultural durante el Pleistoceno tardío e inicio del Holoceno: un enfoque paleopedológico.

The isotopic analyses of bone samples were done in Laboratorio de Isótopos Estables-LANGEM and Pedro Morales Puentes, Edith Cienfuegos Alvarado, Francisco J. Otero and Rafael Puente. We also thank Victor Adrian Pérez Crespo for giving us the results and interpreting them for us.

\section{REFERENCES}

Arroyo-Cabrales, J., Polaco O.J., Johnson, E., 2006, A preliminary view of the coexistence of mammoth and early peoples in México: Quaternary International, 142-143, 79-86.

Back, M. 2014, Fleischer's Glossary of Mineral Species (11 ed.): Tucson, Az. USA, The mineralogical record, $424 \mathrm{pp}$.

Bajnóczi, B., Kovács-Kis, V., 2006, Origin of pedogenic needle-fiber calcite revealed by micromorphology and stable isotope composition-a case study of a Quaternary from Hungary: Chemie der Erde, 66, 203-212.

Becz-Deák, J., Langohr, R., Verrecchia, E.P., 1997, Small scale secondary $\mathrm{CaCO} 3$ accumulations in selected sections of the European loess belt. Morphological forms and potential for paleoenvironmental reconstruction: Geoderma, 76, 221-252.

Berna, F., Matthews, A., Winer, S., 2004, Solubilities of bone mineral from archaeological sites: the recrystallization window: Journal of Archaeological Science, 31, 867-882.
Bocherens, H., 1992, Biogéochimie isotopique (13C, 15N, 18O) et paléontologie des Vertébrés: applications à létude des réseaux trophiques révolus et des paléoenvironnements. Mémoires des Sciences de la Terre no. 92-6: Paris, France, Université Paris 6, PhD. Thesis, 317 pp.

Bocherens, H., Drucker, D.G., Billiou, D., Geneste, J.M., Kervazo, B., 2008, Grotte Chauvet (Ardèche, France): A "natural experiment" for bone diagenesis in karstic context: Palaeogeography, Palaeoclimatology, Palaeoecology, 266, 220-226.

Casal, G.A., Nillini, A., Valle, M.N., González, E., Tiedemann, C., 2017, Premineralización en restos de dinosaurios presents en depósitos de desbordamiento de la formación Bajo Barreal (Cretácico Superior), Patagonia Central, Argentina: Revista Mexicana de Ciencias Geológicas, $34(1), 12-24$.

Chang, L.L.Y., Howie, R.A., Zussman, J., 1996, Rock-Forming minerals: Nonsilicates; Sulphates, Carbonates, Phosphates and Halides: London, The Geological Society, volume 5B, second edition, $383 \mathrm{pp}$.

Chinsamy, A., Raath, M.A., 1992, Preparation of fossil bone for histological examination: Paleontologia Africana, 29, 39-44.

Chinsamy, A., 1997, Assesing the biology of fossil vertebrates trough bone histology: Paleontogia Africana, 33, 29-35.

Cruz-y-Cruz, T., Sánchez, G., Sedov, S., Terrazas-Mata, A., Solleiro-Rebolledo, G., Tovar-Liceaga, R.E., Carpenter, J., 2015, Spatial variability of Late Pleistocene-Early Holocene soil formation and its relation to early human paleoecology in Northwest Mexico: Quaternary International, $365,135-149$

Cruz-y-Cruz, T., Pérez-Crespo, V.A., Pustovoytov, K., Sedov, S., Morales-Puente, P., Tovar-Liceaga, R.E., Arroyo-Cabrales, J., Terrazas-Mata, A., SáchezMiranda, G., 2016, Paleosol (organic matter and pedogenic carbonates) and paleontological $\mathrm{d} 13 \mathrm{C}$ records applied to the paleoecology of late Pleistocene-Holocene in Mexico: Quaternary International, 418, 147-164.

Deer, W.A., Howie, R.A., Zussman J., 2013, An Introduction to the RockForming Minerals: London, The Mineralogical Society, 3rd edition, 528pp.

Durand, N., Curtis, H., Canti, M.G., 2010. Calcium carbonate features, in: Stoops, G., Marcelino, V., Mees, F. (eds.), Interpretation of Micromorphological Features of Soils and Regoliths: Amsterdan, Elsevier, 149-194.

Fernández López, S.R, 1999, Tafonomía y fosilización, in Meléndez, B., (ed.) Tratado de Paleontología, Madrid: España, Consejo Superior de Investigaciones Científicas, 51-107.

Ferrari, L., Orozco, T., Navarro, M., López-Quiroz, P., Luna, L., 2018, Cartografía Geológica Digital y Base de Datos Geocronológica del Cinturón Volcánico Transmexicano y Áreas Contiguas: Terra Digitalis 2(1), 1-8.

Ferrusquía-Villafranca, I., Arroyo-Cabrales, J., Martínez-Hernández, E., GamaCastro, J., Ruiz-González, J., Polaco, O.J., Johnson, E., 2010, Pleistocene mammals of mexico: A critical review of regional chronofaunas, climate change response and biogeographic provinciality: Quaternary International, 217(1), 53-104.

García-Zepeda, M.L., Garduño-Monroy, V.H., 2006, Distribución y nuevos registros de Mammuthus columbi (Falconer) 1857 en el Estado de Michoacán, México: Biológicas, 8, 5-17.

Glimcher, M.J., 1984, Recent studies of the mineral phase in bone and its possible linkage to the organic matrix by protein-bound phosphate bonds: London, Philosophical Transaction of Royal Society of London, Series B 304, 479-508.

Guido, A., Cinzia-Marra, A., Mastandrea, A., Tosti, F., Russo, F., 2012, Micromorphological, geochemical, and diagenetic characterization of sirenian ribs preserved in the Late Miocene paleontological site of Cessaniti (southern Calabria, Italy): Facies, 58, 179-190.

Hackett, C.J., 1981, Microscopical focal destruction. Tunnels in exhumed huma bones: Medicine, Science and Law, 21 (4), 243-265.

Hedges, R.E., 2002, Bone diagenesis: an overview of processes: Archaeometry $44,3,319-328$.

Heine, K., 1984, The classical late Weichselian climatic fluctuations in Mexico, in Mörner, N.A., Karcén, W.D. (eds.), Climatic Changes on a Yearly to Millenial Basis. Geological, historical and instrumental records: Dordrecht, Reidel Publishing Company, 95-115.

Heine, K., Schönhals, E., 1973, Entstehung und Alter der "toba"-Sedimente in Mexiko: Eiszeitalter und Gegenwart, 23-24, 201-215.

Hubert, J.F., Panish, P.T., Chure, D.J., Prostak, K.F., 1996, Chemistry, microstructure, petrology and diagenetic model of Jurassic dinosaur 
bones, dinosaur national monument, Utah: Journal of Sedimentary Research, 66 (3), 431-547.

Hughes, J.M., Rakovan, J.F., 2015, Structurally Robust, Chemically Diverse: Apatite and Apatite Supergroup: Elements, 11(3), 165-170.

Jans, M., 2008, Microbial bioerotion of bone-a review, in Wisshak, M.; Tapanila, L. (eds.), Current Developments in Bioerosion, Erlangen Earth Conference Series: Berlin, Springer-Verlag, 397-413.

Jans, M., Nielsen, Marsh, C.M., Smith, C.I., Collins, M.J.,, Kars, H., 2004 Characterization of microbial attack on archaeological bone: Journal of Archaeological Science, 31, 87-95.

Keenan, S.K., Engel, A.S., Roy, A., Bovenkamp-Langlois, G., 2015, Evaluating the consequences of diagenesis and fossilization on bioapatite lattice structure and composition: Chemical Geology, 413, 18-27.

Klug, H.P., Alexander,L.E., 1974, X-ray Diffraction Procedures for Polycrystalline and Amorphous Materials: London, Wiley Interscience, 1974, 656-690.

Khokhlova, O.S., Sedov, S.N., Golyeva, A.A., Khokhlova, A.A., 2001, Evolution of Chernozems in the Northern Caucasus, Russia during the second half of the Holocene: carbonate status of paleosols as a tool for paleoenvironmental reconstruction: Geoderma, 104, 115-133.

Lamm, E.T., 2007, Paleohistology widens the field of view in paleontology: Micros. Micronala, 13 (2), 50-51.

Lucas, J., Prévôt, L.,1991, Phosphates and Fossil Preservation, in Allison, P.A., Briggs, D.E.G. (eds.), Tophonomy: Releasing the Data Locked in the Fossil Record: New York, Plenum Press, 389-409.

Moore, D., Reynolds, R.C.Jr., 1997, X-Ray Diffraction and the Identification and Analysis of Clay Minerals: Oxford, Oxford University, 2 ed, 332 pp.

Nemliher, J.G., Baturin, G.N., Kallaste, T.E., Murdmaa, L.O., 2004 Transformation of Hydroxyapatite of Bone Phosphate from the Ocean Bottom during Fossilization. Lithology and Mineral Resources, 39(5), 468-479. Translated from Litologiya i Poleznye Iskopaemye, 5, 539-551.

Newesly, H., 1989, Fossil bone apatite, Applied Geochemistry, 4 (3), 233- 245.

O’Brien, G. W., Milnes, A.R., Veeh, H.H., Heggie, D.J., Riggs, S.R.,Cullen, D.J. Marshall, J. F, Cook, P.J., 1990, Sedimentation dynamics and redox ironcycling controlling factors for the apatite-glauconite association on the East Australian Continental margin, in Notholt, A.J.g., Jarvis, I. (eds.), Phosphorite Research and Development: Geological Society, London, Special Publication, 52(1), 61-86.

Pate, F.D., Hutton, J.T., Norrish, K., 1989, Ionic exchange between soil solution and bone: toward a predictive model: Applied Geochemistry, 4, 303-316.

Pérez-Crespo, V., Arroyo-Cabrales, J., Alva-Valdivia, L., Morales-Puente, P., Cienfuegos-Alvarado, E., 2012, Diet and habitat definitions for Mexican glyptodonts from Cedral (San Luis Potosí, México) based on stable isotope análisis: Geological Magazine, 149(1), 153-157, doi:10.1017/ S0016756811000951.

Pérez-Crespo, V., Prado, J.L., Alberdi, M.T., Arroyo-Cabrales, J., Johnson, E., 2016, Diet and habitat for six American Pleistocene proboscidean species using carbon and oxygen stable isotopes: Ameghiniana, 53, 39-51.

Person, A., Bocherens, H., Saliege, J.F., Paris, F., Zeitoun, V., Gerard, M., 1995, Early diagenetic evolution of bone phosphate: an X-ray diffractometry analysis: Journal of Archaeological Science, 22, 211-221.

Peters, F., Schwars, K., Epple, M., 2000, The structure of bone studied with synchrotron $\mathrm{X}$-ray diffraction, $\mathrm{X}$-ray absorption spectroscopy and thermal analysis: Thermochimica Acta, 361, 131-138.

Pfretzschner, H.U., 2004, Fossilization of Haversian bone in aquatic environments: General Paleontology (paleobiochemistry), 3, 605-616.

Piga, G., Santos-Cubedo, A., Moya Sola, S., Brunetti, A., Malgosa, A., Enzo,S., 2009, An X-ray Diffraction (XRD) and X-ray Fluorescence (XRF) investigation in human and animal fossil bones from Holocene to Middle Triassic: Journal of Archaeological Science, 36, 1857-1868.
Reiche, I., Favre-Quattropani, L., Vignaud, C., Bocherens, H., Charlet, L., Menu, M., 2003, A multi analytical study of bonediagenesis: the Neolithic site of Bercy (Paris, France): Measurement Science and Technology, 14, 1608-1619.

Rietveld, H.M., 1967, Line profiles of neutron powder-diffraction peaks for structure refinement: Acta Crystallographica, 22, 151-152.

Robles-Camacho, J., Corona-Chávez, P., Morales-Gámez, M., Guzmán, A.F., Polaco, O.J., Domínguez-Vázquez, G., Israde-Alcántara, I., OliverosMorales, A., 2010, Estratigrafía y paleoambiente asociados a un Gomphoteriidae (Cuvieronius hyodon) en Tzintzuntzan, Michoacán, México: Revista Mexicana de Ciencias Geológicas, 27(3), 530-544.

Sedov, S., Solleiro-Rebolledo, E., Terhorst, B., Solé, J., Flores-Delgadillo, M.L., Werner, G., Poetsch, T., 2009, The Tlaxcala basin paleosol sequence: a multiscale proxy of middle to late Quaternary environmental change in central Mexico: Revista Mexicana de Ciencias Geológicas, 26(2), 448-465.

Sponheimer, M., Lee-Thorp, J., 1999, Alteration of enamel carbonate environments during fossilization: Journal of Archaeological Science, 26, 143-150.

Straulino, L., Sedov, S., Michelet, D., Balanzario, S., 2013, Weathering of carbonate materials in ancient Maya constructions (Río Bec and Dzibanché): Limestone and stucco deterioration patterns: Quaternary Internationaly, 315, 87-100.

Tomassini, R., Miño-Bollini, A.R., Zurita, A., Montalvo, C., Cesaretti, N., 2015, Modificaciones fosildiagenéticas en Toxodon platensis, Owen, 1837 (Notoungulata, toxodontidae) del plehistoceno tardío de la provincia de Corrientes, Argentina: Revista Mexicana de Ciencias Geológicas, 32(2), 283-292.

Tomassini, R., Montalvo, C., Manera, T., Visconti, G., 2014, Mineralogy, Geochemistry and Paleohistology of Pliocen mammals from the Monte Hermoso formation, Argentina, Paedotherium Bonarense (Notoungulata, Hegetotheriidae) as a case study: Ameghiniana, 1(5), 385-395.

Trueman, C.N., Martill, D.M., 2002, The long term survival of bone: the role of bioerosion: Archaeometry, 44(3), 371-382.

Turner-Walker, G., Jans, M., 2008, Reconstructing taphonomic histories using histological analysis: Paleography, Paleoclimatology, Paleoecology, 266, 227-235.

Viñas-Vallverdú, R., Arroyo-Cabrales, J., Rivera-González, I., Rodriguez-Álvarez, X.P., Rubio-Mora, A., Eudave-Eusebio, I., Solís-Torres, O.R., Ardelean, C.F., 2017, Recent archaeo palaeontological findings from Barranca del Muerto site, Santiago Chazumba, Oaxaca, México: Quaternary International, 431, parte b, 160-180.

Verrecchia, E.P., Verrecchia, K.E., 1994, Needle-fiber calcite: a critical review and a proposed classification: Journal of Sedimentary Research, 64, 650-664.

Wings, O., 2004, Authigenic minerals in fossil bones from the Mesozoic of England: poor correlation with depositional environments: Palaeogeography, Palaeoclimatology, Palaeoecology, 204, 15-32.

Wopenka, B; Pasteris, J.A, 2005, Mineralogical perspective on the apatite in bone: Materials Science and Engineering C, 25, 131-143.

Manuscript received: august 21, 2018

Corrected manuscript received: january 26, 2019

Manuscript accepted: february 18, 2019 